\title{
GENDER DIFFERENCES IN COMPETITION: EVIDENCE FROM A MATRILINEAL AND A PATRIARCHAL SOCIETY
}

\author{
By URI GNEEZY, KeNNETH L. LEONARD, AND JOHN A. LIST ${ }^{1}$
}

\begin{abstract}
We use a controlled experiment to explore whether there are gender differences in selecting into competitive environments across two distinct societies: the Maasai in Tanzania and the Khasi in India. One unique aspect of these societies is that the Maasai represent a textbook example of a patriarchal society, whereas the Khasi are matrilineal. Similar to the extant evidence drawn from experiments executed in Western cultures, Maasai men opt to compete at roughly twice the rate as Maasai women. Interestingly, this result is reversed among the Khasi, where women choose the competitive environment more often than Khasi men, and even choose to compete weakly more often than Maasai men. These results provide insights into the underpinnings of the factors hypothesized to be determinants of the observed gender differences in selecting into competitive environments.
\end{abstract}

KEYWORDS: Gender and competition, matrilineal and patriarchal societies, field experiment.

\section{INTRODUCTION}

AlTHOUGH WOMEN HAVE MADE important strides in catching up with men in the workplace, a gender gap persists both in wages and in prospects for advancement. Commonly cited explanations for such disparities range from charges of discrimination to claims that women are more sensitive than men to work-family conflicts and therefore are less inclined to make career sacrifices. ${ }^{2}$ Combining results from psychology studies (see Campbell (2002), for a review) with recent findings in the experimental economics literature (e.g., Gneezy, Niederle, and Rustichini (2003), Gneezy and Rustichini (2004), Niederle and Vesterlund (2005)), an alternative explanation arises: men are more competitively inclined than women. ${ }^{3}$ A stylized finding in this literature is that men and women differ in their propensities to engage in competitive activities, with men opting to compete more often than women, even in tasks where women are more able. Such data patterns might provide insights into why we observe a higher fraction of women than men among, for example, grammar school teachers, but the reverse among CEOs.

An important puzzle in this literature relates to the underlying factors responsible for the observed differences in competitive inclinations. One oft

\footnotetext{
${ }^{1}$ We thank our research team for aiding in the collection of these data, especially Steffen Andersen. A co-editor was instrumental in guiding us toward a much improved manuscript, both in content and in style. Four anonymous referees also provided quite useful comments, as did many seminar participants.

${ }^{2}$ See Altonji and Blank (1999), Blau and Kahn (1992, 2000), and Blau, Ferber, and Winkler (2002).

${ }^{3}$ See also Vandegrift, Yavas, and Brown (2004), Gneezy and Rustichini (2005), and Datta Gupta, Poulsen, and Villeval (2005).
} 
heard hypothesis is that men and women are innately different (Lawrence (2006)). For example, in discussions concerning why men considerably outnumber women in the sciences, several high profile scholars have argued that men are innately better equipped to compete (see, e.g., Baron-Cohen (2003), Lawrence (2006), and the citations in Barres (2006)). An empirical regularity consistent with this notion is the fact that substantial heterogeneity exists in the competitiveness of individuals raised in quite similar environments; see, for example, the discussion of the tendency to compete in bargaining (Shell (2006)).

Nevertheless, the role of nurture, or the fact that culture might be critically linked to competitive inclinations, is also an important consideration. More than a handful of our male readership can likely recall vividly their grammar school physical education teacher scorning them with the proverbial "you're playing like a girl" rant to induce greater levels of competitive spirit. Clearly, however, the explanations might not be competing; rather the nature-nurture interaction might be of utmost importance, either because nurture enables the expression of nature (Turkheimer (1998, 2003), Ridley (2003)) or because nature and nurture co-evolve (Boyd and Richerson (1985, 2005)).

Our goal in this study is to provide some insights into the underpinnings of the observed differences in competitiveness across men and women using a simple experimental task. One approach to lending insights into the source of such preference differences is to find two distinct societies and observe choices that provide direct insights into the competitiveness of the participants. After months of background research, we concluded that the Maasai tribe of Tanzania and the Khasi tribe in India provided interesting natural variation that permitted an exploration into the competitiveness hypothesis. As explained in greater detail below, while several other potentially important factors vary across these societies, the Maasai represent a patriarchal society, whereas the Khasi are a matrilineal and matrilocal society.

Our experimental results reveal interesting differences in competitiveness: in the patriarchal society, women are less competitive than men, a result consistent with student data drawn from Western cultures. Yet, this result reverses in the matrilineal society, where we find that women are more competitive than men. Perhaps surprisingly, Khasi women are even slightly more competitive than Maasai men, but this difference is not statistically significant at conventional levels under any of our formal statistical tests. We view these results as providing potentially useful insights into the crucial link between culture and behavioral traits that influence economic outcomes. ${ }^{4}$ Such insights might also have import within the policy community where targeting of policies can be

\footnotetext{
${ }^{4}$ As we discuss below, this result might be due to learning or an evolutionary process whereby the selection effects across societies generate natural differences. We argue that, in either case, culture has an influence.
} 
importantly misguided if the underlying mechanism generating the data is ill understood.

The remainder of our study proceeds as follows. The next section provides an overview of the two societies and our experimental design. We proceed to a discussion of the experimental results in Section 3. Section 4 provides various robustness tests, Section 5 concludes.

\section{SOCIETAL BACKGROUND AND EXPERIMENTAL DESIGN}

We are sick of playing the roles of breeding bulls and baby-sitters.

A Khasi man (Ahmed (1994))

Men treat us like donkeys.

A Maasai woman (Hodgson (2001))

\subsection{Brief Societal Backgrounds}

The Maasai and the Khasi represent, respectively, a patriarchal and a matrilineal/matrilocal society. Originally, we attempted to find two societies in which the roles of men and women were mirror images, but this approach found little success. Indeed, the sociological literature is almost unanimous in the conclusion that truly matriarchal societies no longer exist. ${ }^{5}$ In addition, even ordinal classification of societies on any dimension is dangerous, as culture and society are not static fixtures handed down from prehistory. Certain reports of extreme female domination in the Khasi or strong male domination among the Maasai are somewhat exaggerated and subject to charges of ethnocentrism. ${ }^{6}$

\section{The Khasi}

The Khasi of Meghalaya, in northeast India are a matrilineal society, and inheritance and clan membership always follow the female lineage through the youngest daughter. Family life is organized around the mother's house, which is headed by the grandmother who lives with her unmarried daughters, her youngest daughter (even if she is married), and her youngest daughter's children. Additionally, her unmarried, divorced, or widowed brothers and sons reside in the home. The youngest daughter never leaves and eventually becomes the head of the household; older daughters usually form separate households adjacent to their mother's household. Furthermore, a woman never joins

\footnotetext{
${ }^{5}$ Campbell (2002) summarized as follows: "there are societies that are matrilineal and matrilocal and where women are accorded veneration and respect but there are no societies which violate the universality of patriarchy defined as 'a system of organization in which the overwhelming number of upper positions in hierarchies are occupied by males' (Goldberg, 1993, p. 14).”

${ }^{6} \mathrm{About}$ the Maasai in particular, there is a vigorous debate on the current and historical role of women (see Hodgson $(2000,2001)$ and Spencer $(1965,1994))$.
} 
the household of her husband's family and a man usually leaves his mother's household to join his wife's household. In some cases, a man will practice duolocal marriage (in which he lives in both his mother's and his wife's households). Even in cases when a married man resides with his wife's family, he spends much, if not most, of his time in his mother's or sisters' household (Nakane (1967), Van Ham (2000)).

Though Khasi women do not generally assume the roles held by men in patriarchal societies (they do not become warriors or hunters, for example), they always live in households in which they or their mothers have authority over most household decisions. On the other hand, men frequently hold roles that seem to mirror those of women in patriarchal societies. The Khasi husband dwells in a household in which he has no authority or property, is expected to work for the gain of his wife's family, and has no social roles deemed important. His role is summarized by Nakane (1967, p. 125), who provided accounts of the subservient role of Khasi men. Such status has lead to the formation of a men's rights movement (Nonbgri (1988), Ahmed (1994), Van Ham (2000)).

Perhaps the most important economic feature of Khasi society is that the return to unverifiable investment in the human capital of girls is retained within the household, whereas, in other cultures, only the verifiable component of investment can be retained through bride price or dowry. In other words, Khasi families can choose to raise exactly the daughter they would like to keep in their household, not the daughter most likely to be preferred by other households.

\section{The Maasai}

Age and cattle dominate the Maasai social structure. The most important distinctions between men are age-based, and almost all wealth is in cattle. The age structure prevents men from marrying until they are roughly 30 years old and polygamy is the most common form of marriage. Therefore, the average Maasai woman is married to a much older man who typically entertains multiple wives (Spencer (2003)).

The plight of women among the Maasai is such that wives are said to be less important to a man than his cattle. For example, daughters are not counted in response to the question "How many children do you have?" and a Maasai man will refer to his wife and children as "property." When their husband is absent, most Maasai women are required to seek permission from an elder male before they travel any significant distance, seek health care, or make any other important decision. Although few Maasai receive any formal education, women receive even less education than men. Their restricted roles and authority combined with the inequality of age in marriage noticeably influence the view that married women have of their roles in society. Of Samburu women (who are part of the larger Maa ethnic group and are very similar to the Maasai), Spencer (1965, p. 231) noted: 
On the whole I found women were quite ignorant of many aspects of the total society and usually unhelpful as informants. Outside the affairs of their own family circle they often showed certain indifference. They were less inquisitive than the males and less quick to grasp situations. They found it harder to comprehend my remarks and questions. I had the impression that they had never been encouraged to show much initiative on their own, and this was a quality which they simply had not developed; any inborn tendencies to this had been baulked by the strictness of their upbringing. Their demeanor was sometimes listless and frequently sour. They often lacked the general conviviality and warmth that typified the adult males and it was only with ameliorating circumstances of middle-age that they tended to acquire it-and many never did.

Despite these stark differences, there are important similarities between the two societies. Khasi men are more important in their sisters' households than in their wives' households, and Maasai women can enjoy prestige and power in their roles as widows (if they have sons). ${ }^{7}$ Despite the fact that the Khasi elevate the importance of women and the historical evidence that they invest significantly in the human capital of their daughters, ${ }^{8}$ many important decisions in Khasi society remain the domain of men. Women do not participate in politics, civil defense, or justice, and priesthood is a male profession (Nongbri (2003)). Additionally, there is evidence that women who attempt to speak about such domains are chastised. ${ }^{9}$

\subsection{Experimental Design}

To provide insights into whether there are gender differences in competitive choices across these two societies, we design an experiment that is identical in the two environments. In each session we recruited the participants in advance and asked each potential subject to arrive at a central place in the village (either the school or the clinic) at a given time. This attenuated selection problems since everyone was interested in participating in the experiment after they were made aware of the pecuniary incentives involved. The experiment with the Maasai was conducted in two villages in the Arumeru district in the Arusha region of Tanzania. The experiment with the Khasi was conducted in the Meghalaya region of India. Upon arrival at each experimental site, participants were directed into one of two groups randomly. These groups were separated for the entire experiment.

Similar procedures were used across the societies to ensure comparability. For example, in a representative session among the Maasai, the actual experiment was conducted around a small house with four sides, called side 1, 2, 3,

\footnotetext{
${ }^{7}$ See Hodgson $(2000,2001)$ for a more nuanced discussion of the Maasai and Samburu, and Lesorogol (2003) for more evidence of the attitudes of the Samburu in an experimental context.

${ }^{8}$ A report from the Agro-Economic Research Centre for northeast India (1969) noted the very high levels of school attendance among the Khasi, and particularly the fact that almost all girls were in school at a time when few girls from other tribes ever attended school.

9 "A woman who dares to voice her opinion on public affairs is regarded as a 'hen that crows'a freak of nature" (Nongbri (2003, p. 187)).
} 
and 4 . The structure was such that each side of the house was private and could not be observed from any of the other sides. Subjects in each group were seated on two different sides of the small house: group 1 was seated on side 1 and group 2 was seated on side 2 . One by one we privately called participants-one from each group - to the experimental area. Members of group 1 were called to side 3 and members of group 2 were called to side 4 . Participants did not know the identities of participants in the other group. On each of those sides was an experimenter awaiting the participants. In a second Maasai session, we were able to use four empty classrooms, similarly isolated from each other. The setup was otherwise identical. The Khasi sessions were run similarly in a classroom setting.

When a participant moved to the area where the experiment was being conducted, he/she met an experimenter who explained the task. Instructions used in the Khasi sessions are reproduced in Appendix A; the Maasai instructions are identical (both sets of original instructions are available at www.arec.umd.edu/kleonard). The instructions were translated from English to the local language (either Maasai or Khasi) and were checked by having a different person translate them back into English. The instructions were read aloud to the individual participant by the experimenter. In each session we had one male and one female experimenter to control for possible gender effects of the experimenter, and we balanced the gender of the participants to have an equal ratio of male and female participants per experimenter.

The experimental task was to toss a tennis ball into a bucket that was placed 3 meters away. Participants were informed that they had 10 chances. A successful shot meant that the tennis ball entered the bucket and stayed there. The task was chosen because it was simple to explain and implement, and no gender differences in ability were expected (as was found in a pilot experiment and reinforced in the results discussed below). Furthermore, we are aware of no other popular task in these societies that is similar to the ball games that we implemented. Indeed, the Khasi are known archers and the Maasai are known lancers, but since our task can only be completed with an underhand toss, the traditional skills do not advantage men over women. In this spirit, our data represent signals of initial competitive inclinations since the task is unfamiliar (Harrison and List (2004), denote such an approach as an artefactual field experiment).

Participants, who numbered 155 in total, were told that they were matched with a participant from the other group who was performing the same task at the same time in another area. For example, in the Maasai representative session discussed above, a group 1 member on side 3 was anonymously paired with a group 2 member on side 4, and both subjects were informed that their identities would remain anonymous. The only decision participants were asked to make concerned the manner in which they would be paid for their performance. They made this choice before performing the task, but only after they fully understood the instructions and the payment schemes. The two options 
participants were asked to choose between were (a) $X$ per successful shot, regardless of the performance of the participant from the other group with whom they were randomly matched or (b) $3 X$ per successful shot if they outperformed the other participant. They were told that in case they chose the second option and scored the same as the other participant, they would receive $X$ per successful shot. We set $X$ to equalize payments in terms of the prevailing exchange rates, and therefore, set $X$ equal to 500 Tanzanian shillings in Tanzania and 20 rupees in India.

After choosing the incentive scheme, participants completed the task and were told how the other participant performed. Then they were asked to proceed to another location where they provided personal information in an exit survey (see Appendix B for the experimental survey) and were paid their earnings in cash. As promised, participants were never given the opportunity to learn with whom they were paired.

\section{RESULTS}

Summary data from the postexperiment survey are presented in Table $\mathrm{I}^{10}$ We present all information drawn from the survey, which includes queries on gender, age, years of education, income, marital status, wage earning activities, and relation to head of household. Our average subject was in the 30-40 year old age range, but the Maasai sample had slightly older subjects. Average educational attainment is roughly similar across the two groups-about 4 years of education-but is slightly higher for women (men) among the Khasi (Maasai). Income levels show similar patterns: Khasi women earn more than Khasi men, and the qualitative nature of this result is reversed among the Maasai. Considering purchasing power, the Khasi earn more than the Maasai, though if we delete one extreme Khasi outlier, the numbers are similar. Activities across the societies, marital status, and relation to head of household differences are consonant with past anthropological evidence. For example, as suggested above, the Khasi tribe is a monogamous group, whereas polygamy is practiced among the Maasai. The differences in observable characteristics across gender, both intra- and intersociety, highlight that it is important to control for as many of these factors as possible when examining the data. For example, variables such as income might importantly influence play and relationship to head of household might provide an indication of control over income. Even after this is done, however, there might remain a critical vector of other variables (whether gambling is condoned, wealth, etc.) that might vary between the societies other than the role of women. Clearly, this issue is central to inference made from data gathered across any distinct groups, and it highlights that care should be

\footnotetext{
${ }^{10}$ The Maasai sample does not sum to 75 (34 women and 40 men). This is because one participant failed to complete the survey after the task. This person chose not to compete and had one success.
} 
TABLE I

PARTICIPANT CHARACTERISTICS ${ }^{\mathrm{a}}$

\begin{tabular}{|c|c|c|c|c|c|c|}
\hline \multirow{2}{*}{$\begin{array}{l}\text { Individual } \\
\text { Characteristics }\end{array}$} & \multicolumn{3}{|c|}{$\begin{array}{c}\text { Khasi } \\
\text { Mean } \\
\text { (Std. Dev.) } \\
\end{array}$} & \multicolumn{3}{|c|}{$\begin{array}{c}\text { Maasai } \\
\text { Mean } \\
\text { (Std. Dev.) }\end{array}$} \\
\hline & Pooled & Women & Men & Pooled & Women & Men \\
\hline Age & $\begin{array}{c}30.9 \\
(16.1)\end{array}$ & $\begin{array}{c}32.1 \\
(16.7)\end{array}$ & $\begin{array}{c}28.8 \\
(15.0)\end{array}$ & $\begin{array}{c}37.8 \\
(13.5)\end{array}$ & $\begin{array}{c}36.5 \\
(12.1)\end{array}$ & $\begin{array}{c}38.9 \\
(14.6)\end{array}$ \\
\hline Education & $\begin{array}{c}4.3 \\
(3.6)\end{array}$ & $\begin{array}{c}4.5 \\
(3.6)\end{array}$ & $\begin{array}{c}4.1 \\
(3.5)\end{array}$ & $\begin{array}{c}4.3 \\
(3.9)\end{array}$ & $\begin{array}{c}4.1 \\
(4.4)\end{array}$ & $\begin{array}{c}4.5 \\
(3.5)\end{array}$ \\
\hline Income & $\begin{array}{c}23,569 \\
(76,088)\end{array}$ & $\begin{array}{c}25,794 \\
(93,429)\end{array}$ & $\begin{array}{c}19,437 \\
(20,585)\end{array}$ & $\begin{array}{c}195,040 \\
(400,538)\end{array}$ & $\begin{array}{c}154,294 \\
(341,903)\end{array}$ & $\begin{array}{c}234,550 \\
(448,855)\end{array}$ \\
\hline \multicolumn{7}{|l|}{ Activity } \\
\hline Farmer & $0.60(0.5)$ & $0.60(0.5)$ & $0.61(0.5)$ & $0.73(0.5)$ & $0.53(0.5)$ & $0.93(0.3)$ \\
\hline Student & $0.23(0.4)$ & $0.21(0.1)$ & $0.25(0.4)$ & $0.00(0.0)$ & $0.00(0.0)$ & $0.00(0.0)$ \\
\hline Teacher & $0.05(0.2)$ & $0.06(0.2)$ & $0.04(0.2)$ & $0.00(0.0)$ & $0.00(0.0)$ & $0.00(0.0)$ \\
\hline Housewife & $0.01(0.1)$ & $0.00(0.0)$ & $0.04(0.2)$ & $0.17(0.4)$ & $0.38(0.5)$ & $0.00(0.0)$ \\
\hline Other & $0.05(0.2)$ & $0.06(0.2)$ & $0.04(0.2)$ & $0.07(0.3)$ & $0.06(0.2)$ & $0.08(0.3)$ \\
\hline Unemployed & $0.06(0.2)$ & $0.08(0.3)$ & $0.04(0.2)$ & $0.00(0.0)$ & $0.00(0.0)$ & $0.00(0.0)$ \\
\hline \multicolumn{7}{|l|}{ Marital status } \\
\hline Single & $0.36(0.5)$ & $0.33(0.5)$ & $0.43(0.5)$ & $0.24(0.4)$ & $0.18(0.4)$ & $0.30(0.5)$ \\
\hline Marr. (mono.) & $0.44(0.5)$ & $0.42(0.5)$ & $0.46(0.5)$ & $0.32(0.5)$ & $0.38(0.5)$ & $0.28(0.5)$ \\
\hline Marr. (poly.) & $0.00(0.0)$ & $0.00(0.0)$ & $0.00(0.0)$ & $0.36(0.5)$ & $0.35(0.5)$ & $0.38(0.5)$ \\
\hline Widowed & $0.13(0.3)$ & $0.17(0.4)$ & $0.04(0.2)$ & $0.01(0.1)$ & $0.03(0.2)$ & $0.00(0.0)$ \\
\hline Divorced & $0.08(0.3)$ & $0.08(0.3)$ & $0.07(0.3)$ & $0.04(0.2)$ & $0.03(0.2)$ & $0.05(0.2)$ \\
\hline \multicolumn{7}{|c|}{ Relation to head of household } \\
\hline $\mathrm{HH}$ & $0.38(0.5)$ & $0.39(0.5)$ & $0.36(0.5)$ & $0.53(0.5)$ & $0.18(0.4)$ & $0.85(0.4)$ \\
\hline Spouse & $0.23(0.4)$ & $0.29(0.5)$ & $0.11(0.3)$ & $0.32(0.5)$ & $0.71(0.5)$ & $0.00(0.0)$ \\
\hline Son/daughter & $0.36(0.5)$ & $0.31(0.5)$ & $0.46(0.5)$ & $0.09(0.3)$ & $0.03(0.2)$ & $0.15(0.4)$ \\
\hline Brother/sister & $0.04(0.2)$ & $0.02(0.1)$ & $0.07(0.3)$ & $0.00(0.0)$ & $0.00(0.0)$ & $0.00(0.0)$ \\
\hline Father/mother & $0.00(0.0)$ & $0.00(0.0)$ & $0.00(0.0)$ & $0.03(0.2)$ & $0.06(0.2)$ & $0.00(0.0)$ \\
\hline$N$ & 80 & 52 & 28 & 75 & 34 & 40 \\
\hline
\end{tabular}

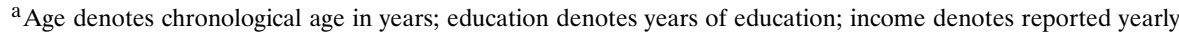
income (Khasi in rupees and Maasai in Tanzanian shillings); marital status denotes whether the individual is single, married (monogamous), married (polygamous), widowed, or divorced; activity denotes the wage earning activities that subjects report; relation to head of household denotes whether the individual is the household head (HH), spouse, son/daughter, brother/sister, or father/mother of the HH. The Maasai women and men observations do not sum to the total observations because we failed to obtain the gender of one participant.

taken when making inference from the data patterns observed herein. Ultimately, what is necessary to shed light on these issues is to build on our work by studying other matrilineal societies.

The top panel in Table II provides a summary of competitive choices, balls successfully tossed in the bucket, and earnings across gender and societies. Figure 1 complements these summary data with an ocular depiction of the observed choices. In terms of task proficiency, subjects made roughly 25 percent 
TABLE II

PARTICIPANT CHOICES ${ }^{\mathrm{a}}$

\begin{tabular}{|c|c|c|c|c|c|c|}
\hline & \multicolumn{3}{|c|}{$\begin{array}{c}\text { Khasi } \\
\text { Mean } \\
\text { (Std. Dev.) }\end{array}$} & \multicolumn{3}{|c|}{$\begin{array}{c}\text { Maasai } \\
\text { Mean } \\
\text { (Std. Dev.) }\end{array}$} \\
\hline & Pooled & Women & Men & Pooled & Women & Men \\
\hline \multicolumn{7}{|l|}{ Experiment summary } \\
\hline Compete & $\begin{array}{l}0.49 \\
(0.5)\end{array}$ & $\begin{array}{l}0.54 \\
(0.5)\end{array}$ & $\begin{array}{l}0.39 \\
(0.5)\end{array}$ & $\begin{array}{l}0.39 \\
(0.5)\end{array}$ & $\begin{array}{l}0.26 \\
(0.5)\end{array}$ & $\begin{array}{l}0.50 \\
(0.5)\end{array}$ \\
\hline Success & $\begin{array}{l}2.38 \\
(1.5)\end{array}$ & $\begin{array}{l}2.38 \\
(1.6)\end{array}$ & $\begin{array}{l}2.36 \\
(1.4)\end{array}$ & $\begin{array}{l}2.78 \\
(1.6)\end{array}$ & $\begin{array}{l}2.97 \\
(1.7)\end{array}$ & $\begin{array}{l}2.63 \\
(1.5)\end{array}$ \\
\hline Earnings & $\begin{array}{l}3.46 \\
(3.9)\end{array}$ & $\begin{array}{l}3.73 \\
(4.2)\end{array}$ & $\begin{array}{l}2.96 \\
(3.3)\end{array}$ & $\begin{array}{l}4.02 \\
(4.3)\end{array}$ & $\begin{array}{l}3.68 \\
(4.0)\end{array}$ & $\begin{array}{l}4.33 \\
(4.5)\end{array}$ \\
\hline$N$ & 80 & 52 & 28 & 74 & 34 & 40 \\
\hline \multicolumn{7}{|c|}{ Those who chose to compete } \\
\hline Success & $\begin{array}{l}2.23 \\
(1.5)\end{array}$ & $\begin{array}{l}2.25 \\
(1.5)\end{array}$ & $\begin{array}{l}2.18 \\
(1.5)\end{array}$ & $\begin{array}{l}2.69 \\
(1.6)\end{array}$ & $\begin{array}{l}2.33 \\
(2.2)\end{array}$ & $\begin{array}{l}2.85 \\
(1.3)\end{array}$ \\
\hline Won-loss-tie & $16-14-9$ & $13-10-5$ & $3-4-4$ & $14-13-2$ & $3-6-0$ & $11-7-2$ \\
\hline Earnings & $\begin{array}{l}4.46 \\
(5.2)\end{array}$ & $\begin{array}{l}4.75 \\
(5.3)\end{array}$ & $\begin{array}{l}3.72 \\
(5.0)\end{array}$ & $\begin{array}{l}5.86 \\
(6.2)\end{array}$ & $\begin{array}{l}5.00 \\
(7.7)\end{array}$ & $\begin{array}{l}6.25 \\
(5.6)\end{array}$ \\
\hline \multicolumn{7}{|c|}{ Those who chose not to compete } \\
\hline Success & $\begin{array}{l}2.51 \\
(1.5)\end{array}$ & $\begin{array}{l}2.54 \\
(1.6)\end{array}$ & $\begin{array}{l}2.47 \\
(1.4)\end{array}$ & $\begin{array}{l}2.84 \\
(1.6)\end{array}$ & $\begin{array}{l}3.20 \\
(1.4)\end{array}$ & $\begin{array}{l}2.40 \\
(1.7)\end{array}$ \\
\hline Won-loss-tie & $18-20-3$ & $11-11-2$ & $7-9-1$ & $19-18-8$ & $9-9-7$ & $10-9-1$ \\
\hline $\begin{array}{l}\text { Earnings if } \\
\quad \text { choice reversed }\end{array}$ & $\begin{array}{l}4.95 \\
(5.9)\end{array}$ & $\begin{array}{l}5.42 \\
(6.2)\end{array}$ & $\begin{array}{l}4.29 \\
(4.3)\end{array}$ & $\begin{array}{l}5.42 \\
(6.2)\end{array}$ & $\begin{array}{l}5.60 \\
(6.2)\end{array}$ & $\begin{array}{l}5.20 \\
(6.3)\end{array}$ \\
\hline
\end{tabular}

${ }^{a}$ Compete denotes whether the individual opted to compete in the experiment; success denotes the number of successful attempts in the experiment (out of 10 balls tossed); earnings denotes the units earned during the experiment, where the units = successes if the agent chose not to compete, successes multiplied by 3 if the agent chose to compete and won, $=$ successes if the agent chose to compete and tied, and $=0$ if the agent chose to compete and lost; earnings if choice reversed denotes the units foregone because the agent chose not to compete.

of their attempts, and the rates of success are similar across societies and genders within each society. More importantly for our purposes, roughly half of the Khasi subjects opted to compete, whereas only 39 percent of the Maasai chose to compete. When broken down by gender, the underlying force behind the competitiveness differences across the two societies becomes clear.

In the Maasai data, the gender result that we oftentimes observe in the literature is evident: whereas 50 percent of men choose to compete, only 26 percent of women select to compete. Alternatively, as Figure 1 highlights, Khasi women choose to compete more often than Khasi men-whereas 54 percent of Khasi women choose to compete, only 39 percent of Khasi men select the competitive incentive scheme. Perhaps even more surprisingly, the Khasi women 


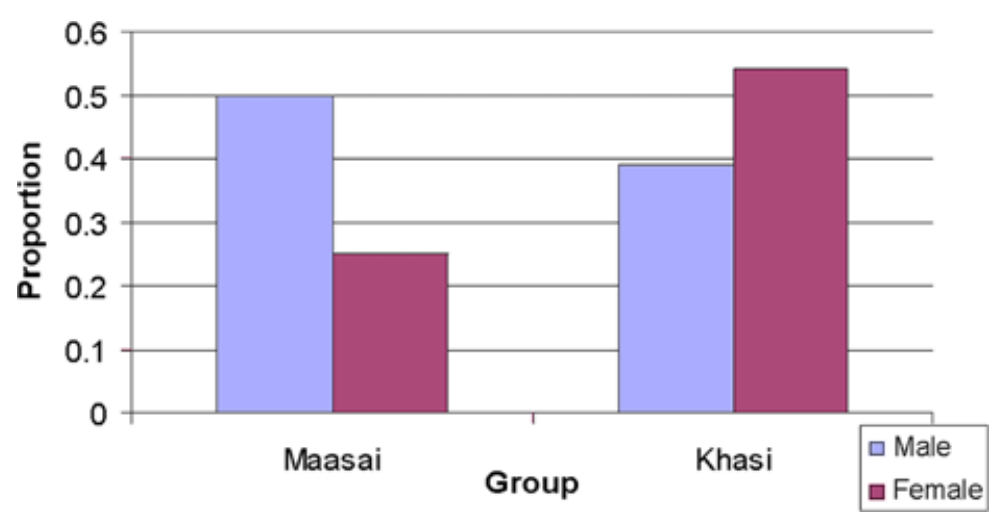

FIGURE 1.-A summary of competitive choices across gender in the two societies.

select the competitive environment more often than the Maasai men (54\% versus $50 \%$ ).

Although the raw data summary provides some evidence that behavior varies across the two societies, there has been no attempt to control for observablessuch as age, education, and income-that might influence behavior. To rectify this situation, we use the individual observations to estimate a regression model in which we regressed the individual choice to compete on a dummy variable for society, a dummy variable for gender, their interaction, the observables collected from our survey detailed in Table I, and the gender of the experimenter. Due to the dichotomous nature of the regressand, we present estimates from a probit model.

Empirical results from several specifications are contained in Table III. The leftmost regression models in Table III pool the Khasi and Maasai data, and provide a sense of the data patterns across the two societies. The rightmost columns split the data by society, permitting the controls to have a heterogeneous effect in the two societies. Specification 1 (S1) can be considered the parsimonious specification, including only variables that provide the unconditional effect of gender on competition and a control for the gender of the experimenter (male exp. $=1$ for male experimenter, $=0$ for female experimenter). Specification 2 (S2) adds the individual level variables to S1-age, education, and income-that might be most expected to influence competitive tendencies. Specification 3 (S3) augments S2 by including the full set of controls-work activities, marital status, and relationship to head of household. ${ }^{11}$

${ }^{11}$ Given that many of the cells are not well populated for these other controls (see Table II), we (i) made the activity variable binary (farmer or nonfarmer), (ii) we split the marital status variable to also be binary (single or married, where single includes divorced and widowed), and (iii) we split the relation to head of household variable as binary (either head of household or spouse). 
TABLE III

REGRESSION RESULTS ${ }^{\mathrm{a}}$

\begin{tabular}{|c|c|c|c|c|c|c|c|c|c|}
\hline & \multicolumn{3}{|c|}{ Pooled Data } & \multicolumn{3}{|c|}{ Khasi } & \multicolumn{3}{|c|}{ Maasai } \\
\hline & S1 & S2 & S3 & S1 & S2 & S3 & S1 & S2 & S3 \\
\hline Female & $\begin{array}{c}-0.25 \\
(0.12)\end{array}$ & $\begin{array}{c}-0.29 \\
(0.13)\end{array}$ & $\begin{array}{c}-0.32 \\
(0.15)\end{array}$ & $\begin{array}{c}0.15 \\
(0.11)\end{array}$ & $\begin{array}{c}0.24 \\
(0.13)\end{array}$ & $\begin{array}{c}0.24 \\
(0.13)\end{array}$ & $\begin{array}{c}-0.24 \\
(0.12)\end{array}$ & $\begin{array}{c}-0.29 \\
(0.12)\end{array}$ & $\begin{array}{c}-0.27 \\
(0.18)\end{array}$ \\
\hline Khasi & $\begin{array}{c}-0.11 \\
(0.12)\end{array}$ & $\begin{array}{c}-0.14 \\
(0.13)\end{array}$ & $\begin{array}{c}-0.15 \\
(0.14)\end{array}$ & - & - & - & - & - & - \\
\hline Khasi $\times$ female & $\begin{array}{c}0.39 \\
(0.17)\end{array}$ & $\begin{array}{c}0.43 \\
(0.17)\end{array}$ & $\begin{array}{c}0.46 \\
(0.19)\end{array}$ & - & - & - & - & - & - \\
\hline Male exp. & $\begin{array}{r}0.007 \\
(0.08)\end{array}$ & $\begin{array}{c}-0.02 \\
(0.08)\end{array}$ & $\begin{array}{c}-0.03 \\
(0.08)\end{array}$ & $\begin{array}{c}0.08 \\
(0.11)\end{array}$ & $\begin{array}{c}0.19 \\
(0.12)\end{array}$ & $\begin{array}{c}0.18 \\
(0.12)\end{array}$ & $\begin{array}{c}-0.07 \\
(0.12)\end{array}$ & $\begin{array}{c}-0.16 \\
(0.12)\end{array}$ & $\begin{array}{c}-0.21 \\
(0.13)\end{array}$ \\
\hline Constant & $\begin{array}{r}-0.003 \\
(0.09)\end{array}$ & $\begin{array}{l}-0.03 \\
(0.17)\end{array}$ & $\begin{array}{c}-0.09 \\
(0.20)\end{array}$ & $\begin{array}{c}-0.14 \\
(0.11)\end{array}$ & $\begin{array}{c}-0.36 \\
(0.20)\end{array}$ & $\begin{array}{c}-0.34 \\
(0.27)\end{array}$ & $\begin{array}{c}0.03 \\
(0.09)\end{array}$ & $\begin{array}{c}0.14 \\
(0.26)\end{array}$ & $\begin{array}{c}-0.03 \\
(0.31)\end{array}$ \\
\hline Age & - & $\begin{array}{c}0.002 \\
(0.003)\end{array}$ & $\begin{array}{c}0.002 \\
(0.003)\end{array}$ & - & $\begin{array}{c}-0.003 \\
(0.004)\end{array}$ & $\begin{array}{c}-0.002 \\
(0.005)\end{array}$ & - & $\begin{array}{c}0.001 \\
(0.005)\end{array}$ & $\begin{array}{c}0.002 \\
(0.005)\end{array}$ \\
\hline Education & - & $\begin{array}{r}0.005 \\
(0.01)\end{array}$ & $\begin{array}{c}0.009 \\
(0.01)\end{array}$ & - & $\begin{array}{r}0.003 \\
(0.02)\end{array}$ & $\begin{array}{r}0.003 \\
(0.02)\end{array}$ & - & $\begin{array}{c}-0.006 \\
(0.02)\end{array}$ & $\begin{array}{r}-0.004 \\
(0.02)\end{array}$ \\
\hline Income & - & $\begin{array}{r}-0.2 \mathrm{e}-6 \\
(0.2 \mathrm{e}-6)\end{array}$ & $\begin{array}{c}-0.2 \mathrm{e}-6 \\
(0.2 \mathrm{e}-6)\end{array}$ & - & $\begin{array}{c}0.1 \mathrm{e}-4 \\
(0.4 \mathrm{e}-5)\end{array}$ & $\begin{array}{c}0.1 \mathrm{e}-4 \\
(0.4 \mathrm{e}-5)\end{array}$ & - & $\begin{array}{c}-0.3 e-6 \\
(0.2 e-6)\end{array}$ & $\begin{array}{r}-0.3 e-6 \\
(0.2 e-6)\end{array}$ \\
\hline Other controls & No & No & Yes & No & No & Yes & No & No & Yes \\
\hline Chi squared & $7.3(4)$ & $9.8(7)$ & $12.6(10)$ & $2.0(2)$ & $11.4(5)$ & $11.9(8)$ & $4.7(2)$ & $9.3(5)$ & $12.9(8)$ \\
\hline$N$ & 154 & 151 & 151 & 80 & 80 & 80 & 74 & 71 & 71 \\
\hline
\end{tabular}

\footnotetext{
aThe dependent variable is "compete," and it takes on a value of 1 if the participant opted to compete and 0 otherwise. Standard errors are given in parentheses. Estimates are partial derivatives computed at the sample means from probit models. Variables are as defined in the Table I footnote. Male exp. $=1$ if the experimenter was male, $=0$ otherwise. Other controls include all of the other variables defined in Table I.
}

Regardless of which specification is preferred, empirical results suggest that females (males) compete more often than males (females) in the Khasi (Maasai) society. These data patterns are observed in the pooled data models in the leftmost columns, where both the female variable and the Khasi $\times$ female interaction are significant at conventional levels. These results suggest, for example, that among the Maasai, women are roughly 25-32 percent less likely to compete than men. For the Khasi, women are roughly 15 percent more likely to compete than Khasi men. In the pooled data, all of the other control variables, including the gender of the experimenter, are not significant at conventional levels.

Models that use only Khasi data, presented in the middle columns of Table III, reveal that the observed gender differences are marginally significant.

In the pooled regression models these distinctions never matter; these changes are necessary to yield parameter estimates for the models with Khasi or Maasai data only (rightmost columns). We also experimented with higher order age terms, but they were never significant. 
In S1, the differences are not significant at conventional levels, suggesting that unconditionally there is no strong evidence that Khasi females compete more than Khasi males. Yet, in the two models that include controls to condition on observables, the female coefficient of 0.24 is significant at the $p<0.07$ level. These estimates suggest that upon properly controlling for observable differences across subjects, Khasi females are 24 percent more likely to compete than Khasi men. In the robustness tests discussed below, we will find that in most of the empirical specifications this result strengthens.

In the rightmost columns, the specifications using the Maasai data show effects of gender that are opposite to the Khasi data-in two of three models the female coefficient is negative and significant at the $p<0.05$ level, with the full-blown model causing the estimate to be measured imprecisely. Among the Maasai, men are found to be 24-29 percent more likely to compete than women. In the robustness tests discussed below, the Maasai results become less statistically significant in certain models.

Concerning impacts of the other regressors in the society-specific models, in the Khasi data we observe some evidence of an experimenter effect-in this case, both male and female subjects are about 18 percent more likely to compete when the experimenter is a male, an effect that is only marginally significant. In addition, participants with higher incomes opted to compete slightly more often, though again the effect is only marginally significant. Interestingly, the only control variable that approaches statistical significance in the Maasai data is the gender of the experimenter. In this case, subjects tend to compete less when the experimenter is a male, and this effect approaches statistical significance in $\mathrm{S} 3 .^{12}$

\section{ROBUSTNESS TESTS}

\subsection{Group Composition}

One aspect of the experimental design that we chose to remain neutral was the identity of the subject's potential competitor. This choice was in the spirit of the recent literature that begins with an exploration of the underlying subject preferences and leaves the opponent's gender ambiguous (see, e.g., Gneezy, Niederle, and Rustichini (2003)). While in and of itself this choice does not present an inferential problem for our purposes, what is potentially troubling is the fact that our samples are unbalanced across societies: 52 of 80 Khasi subjects are female, whereas only 34 of 74 Maasai subjects are female. If subjects deduced the gender distribution of potential competitors, then our preferred interpretation might be compromised. For example, if women are more likely to compete against other women regardless of whether they are from a matrilineal society, then we might be simply observing a consequence of the subject

\footnotetext{
${ }^{12}$ We interacted gender of the experimenter with subject gender and this variable was never significant in either society.
} 
pool rather than a fundamental preference for competition. Considering the literature on gender and self-identity (Cross and Medson (1977)), this is an important consideration.

As previously mentioned, in each society we executed the treatments in sessions, whereby the subjects in each session were split into one of two groups randomly. These two groups were separated for the entire experiment. Similar procedures were used across the societies to ensure that subjects were unaware of the identity of potential competitors. Importantly for our purposes, in each society subjects were lined up to participate and were called one by one to participate. Whether, and how, subjects deduced the gender composition of potential competitors is unknown, but it is plausible that subjects made inference on the gender distribution in the experiment by what they observed in their own surroundings.

Since we do not know exactly what subjects observed within their own group, we use a broad array of sensitivity checks to model empirically the effect of group composition. This is possible because we have data on the exact order in which subjects completed the experiment within their session. We proceed by exploring "nearest neighbor" variables and systematically enlarging the set as active control variables in the regression model estimated above (S3).

A first empirical augmentation simply includes a variable that depicts the gender of the subject standing immediately in front of the person (where male $=1$ ). The next empirical specification uses the arithmetic average of the gender identity of the directly adjacent subjects. ${ }^{13} \mathrm{~A}$ third model uses the arithmetic average of the gender identity of the four nearest subjects. A fourth model expands this variable to be the average of the gender identity of the eight nearest subjects. A fifth and final model is entirely exhaustive: the arithmetic average of the gender identity of all others in the group.

Table IV contains summary empirical results from estimation of these models. The columns in Table IV represent the various specifications of the group composition variable. The three panels of Table IV present the results for the pooled data, the Khasi data, and the Maasai data, in a manner consonant with Table III. Although all of the controls of S3 are included, we present only the results of interest.

Most importantly, in the pooled data all of the previously discussed empirical results hold across every model, suggesting that we are finding evidence of competitive preference differences across gender, and not merely observing a consequence of the subject pool. When we split the data by society, the results become stronger in certain specifications. For example, in the second column of the middle panel of Table IV (specification "In Front"), we find that

\footnotetext{
${ }^{13}$ This variable equals 1 for those subjects who are standing in line between two men, 0.5 for those subjects standing in line between one man and one woman, and 0 for those subjects who are standing in line between two women. Subjects at the front and end of each line have only one adjacent neighbor.
} 
TABLE IV

GROUP COMPOSITION ROBUSTNESS TESTS ${ }^{\mathrm{a}}$

\begin{tabular}{|c|c|c|c|c|c|}
\hline & \multicolumn{5}{|c|}{ Specification } \\
\hline & In Front & Adjacent 2 & Adjacent 4 & Adjacent 8 & Group \\
\hline \multicolumn{6}{|l|}{ Pooled data } \\
\hline Female & $\begin{array}{c}-0.38 \\
(0.16)\end{array}$ & $\begin{array}{c}-0.42 \\
(0.16)\end{array}$ & $\begin{array}{c}-0.41 \\
(0.16)\end{array}$ & $\begin{array}{c}-0.43 \\
(0.16)\end{array}$ & $\begin{array}{c}-0.38 \\
(0.16)\end{array}$ \\
\hline Khasi & $\begin{array}{c}-0.25 \\
(0.16)\end{array}$ & $\begin{array}{c}-0.28 \\
(0.16)\end{array}$ & $\begin{array}{c}-0.25 \\
(0.15)\end{array}$ & $\begin{array}{c}-0.28 \\
(0.16)\end{array}$ & $\begin{array}{c}-0.23 \\
(0.16)\end{array}$ \\
\hline Khasi $\times$ female & $\begin{array}{c}0.60 \\
(0.22)\end{array}$ & $\begin{array}{c}0.65 \\
(0.23)\end{array}$ & $\begin{array}{c}0.56 \\
(0.20)\end{array}$ & $\begin{array}{c}0.58 \\
(0.20)\end{array}$ & $\begin{array}{c}0.53 \\
(0.20)\end{array}$ \\
\hline $\begin{array}{l}\text { Group } \\
\text { Composition }\end{array}$ & $\begin{array}{c}-0.16 \\
(0.10)\end{array}$ & $\begin{array}{c}-0.19 \\
(0.12)\end{array}$ & $\begin{array}{c}-0.28 \\
(0.17)\end{array}$ & $\begin{array}{c}-0.35 \\
(0.21)\end{array}$ & $\begin{array}{c}-0.23 \\
(0.25)\end{array}$ \\
\hline $\begin{array}{l}\text { Other controls } \\
N\end{array}$ & Yes & $\begin{array}{l}\text { Yes } \\
151\end{array}$ & $\begin{array}{l}\text { Yes } \\
151\end{array}$ & $\begin{array}{l}\text { Yes } \\
151\end{array}$ & $\begin{array}{l}\text { Yes } \\
151\end{array}$ \\
\hline Chi squared & $13.8(11)$ & $15.2(11)$ & $15.4(11)$ & $15.5(11)$ & $13.5(11)$ \\
\hline \multicolumn{6}{|l|}{ Khasi data } \\
\hline Female & $\begin{array}{c}0.36 \\
(0.15)\end{array}$ & $\begin{array}{c}0.34 \\
(0.15)\end{array}$ & $\begin{array}{c}0.24 \\
(0.14)\end{array}$ & $\begin{array}{c}0.25 \\
(0.14)\end{array}$ & - \\
\hline $\begin{array}{l}\text { Group } \\
\text { Composition }\end{array}$ & $\begin{array}{c}-0.28 \\
(0.15)\end{array}$ & $\begin{array}{c}-0.25 \\
(0.18)\end{array}$ & $\begin{array}{c}-0.68 \\
(0.36)\end{array}$ & $\begin{array}{c}-0.95 \\
(0.51)\end{array}$ & - \\
\hline $\begin{array}{l}\text { Other controls } \\
N\end{array}$ & $\begin{array}{l}\text { Yes } \\
78\end{array}$ & $\begin{array}{l}\text { Yes } \\
80\end{array}$ & $\begin{array}{l}\text { Yes } \\
80\end{array}$ & $\begin{array}{l}\text { Yes } \\
80\end{array}$ & - \\
\hline Chi squared & $16.1(9)$ & $13.9(9)$ & $15.6(9)$ & $15.6(9)$ & - \\
\hline \multicolumn{6}{|l|}{ Maasai data } \\
\hline Female & $\begin{array}{c}-0.25 \\
(0.20)\end{array}$ & $\begin{array}{c}-0.27 \\
(0.20)\end{array}$ & $\begin{array}{c}-0.27 \\
(0.19)\end{array}$ & $\begin{array}{c}-0.31 \\
(0.20)\end{array}$ & $\begin{array}{c}-0.34 \\
(0.20)\end{array}$ \\
\hline $\begin{array}{l}\text { Group } \\
\text { Composition }\end{array}$ & $\begin{array}{c}0.09 \\
(0.15)\end{array}$ & $\begin{array}{c}-0.008 \\
(0.17)\end{array}$ & $\begin{array}{r}-0.007 \\
(0.21)\end{array}$ & $\begin{array}{c}-0.12 \\
(0.25)\end{array}$ & $\begin{array}{c}-0.20 \\
(0.27)\end{array}$ \\
\hline $\begin{array}{l}\text { Other controls } \\
N\end{array}$ & $\begin{array}{l}\text { Yes } \\
63\end{array}$ & $\begin{array}{l}\text { Yes } \\
71\end{array}$ & $\begin{array}{l}\text { Yes } \\
71\end{array}$ & $\begin{array}{l}\text { Yes } \\
71\end{array}$ & $\begin{array}{l}\text { Yes } \\
71\end{array}$ \\
\hline Chi squared & $14.2(9)$ & $12.9(9)$ & $12.9(9)$ & $13.2(9)$ & $13.5(9)$ \\
\hline
\end{tabular}

a The dependent variable is "compete," and it takes on a value of 1 if the participant opted to compete and 0 otherwise. Each column represents a unique model that uses a different group composition regressor. "In front" is a variable that depicts the gender of the subject standing immediately in front of the person (where male $=1$ ); "adjacent $n$ " uses the arithmetic average of the gender identity of the directly adjacent $n$ subjects. "Group" is entirely exhaustive-the arithmetic average of the gender identity of all others in the group — this model is not estimable using the Khasi data alone because each group had an identical composition. Standard errors are given in parentheses. Estimates are partial derivatives computed at the sample means from probit models. Variables are defined in the Table I footnote. "Other controls" include all of the other variables defined in Table I.

in the Khasi data, women are 36 percent more likely to compete than men, a coefficient that is significant at the $p<0.01$ level. Although in this same empirical specification, the Maasai gender result is not close to being significant at conventional levels, it gains marginal significance as the group composition variable becomes more encompassing. 
Concerning the effects of the group composition variable, which are only marginally significant, we find a negative correlation in the pooled data. Yet, in the Khasi data, we observe a more consistent negative effect that gains statistical significance in some of the specifications, particularly in the models that allow a broader scope of peer effects. The inference from these models is that as the proportion of males increases in your group, the probability of choosing the competitive option decreases. The effect is also found to be negative in most of the specifications using the Maasai sample, but the $t$-ratios on these coefficients never reach unity. Overall, if subjects were making inference on potential competitors based on the mix they observed, then the effects reported in Table IV are consonant with the notion that women are more likely to compete against other women, especially in matrilineal societies.

\subsection{An Exploration Into Who Competes}

Recall that our design was chosen to explore initial competitive inclinations, rather than observe choices in games that were commonplace. In doing so, we aim to capture insights into the primitive competitive preferences among agents rather than the preferences bundled with stereotypes on task, societal expectations, and the like. In this manner, it is interesting to examine the success rates among those who chose to compete versus those who chose not to compete. Since the experimental game is like no other game or task in which the agents in either society typically participate, we do not have strong priors on whether those who are more efficient at task will choose to compete.

This is buttressed by the results in the literature that find even in those cases where the subjects have just executed the task and received performance feedback, those who perform well are not significantly more likely to compete or to perform better if they do choose to compete (Niederle and Vesterlund (2007); see also Datta Gupta, Poulsen, and Villeval (2005)). The expected positive relationship between task proficiency and selection into the competitive setting is further muddled if one considers results in Gneezy, Niederle, and Rustichini (2003), which suggest the competitive environment itself might induce differences in task proficiency. Together, the literature teaches us that any effort to deduce selection is quite difficult, even in experienced tasks. Our experimental game therefore represents a particularly demanding task in which to find a positive correlation between the competitive choice and success rates.

The raw statistics in the middle and bottom portions of Table II paint a picture consonant with the literature-we find no evidence of any significant correlation in task proficiency and the decision to compete. What is interesting in the data is that Khasi women and Maasai men who chose to compete (i) earned the highest amount of money in their respective societies and (ii) were most likely to win the competition. For instance, the Khasi women won 13 times and lost 10, and their win rate represents the highest of any of the four Khasi groups. Compared to Maasai women, Khasi women are more likely to select 
correctly, perhaps because Khasi women have a more accurate sense of their relative abilities. ${ }^{14}$ Similar data patterns are observed among Maasai men, where those who chose to compete won 11 times and lost 7, a win rate that exceeded all the other observed win rates. Furthermore, again we find that Maasai men seem to have a better understanding of relative ability than Khasi men. Clearly, however, these data patterns should be considered as only suggestive, as more work is necessary to further our understanding of the sources of such differences.

\subsection{Risk Aversion}

One aspect of the results in Table II and the broader results reported in this study that should be considered more carefully is whether risk aversion is playing an important role in individual choices. We should stress that the manner in which we use the term "competitiveness" in this study is meant to be a catchall phrase that might be due to deeper underlying preferences, such as risk aversion. Nevertheless, risk aversion might explain the data patterns observed in Table II if the more able participants also happen to be the most risk averse. In addition, the fact that a large portion of subjects did not choose to competeeven though, with our payoff function, they should enter the competition if they believe that they would win with at least 33 percent probability-hints at some level of risk aversion. This possibility is particularly possible in our experiments since they might well be considered to be over large stakes (several days' wages).

To lend insights into these issues, we conducted parallel risk aversion experiments to explore whether the competitive differences might be driven by heterogeneous risk postures across gender groups. To operationalize a simple procedure that measures the propensity to take risks, we made use of a standard risk game (Gneezy and Potters (1997), Haigh and List (2005)) and followed the procedures in these studies as closely as possible. ${ }^{15}$ Appendix $\mathrm{C}$ contains the experimental instructions.

Briefly, the risk experiment has subjects play a one-shot game in which they are endowed with 100 units (40 rupees for the Khasi and 1000 shillings for the Maasai). The subject must decide what portion of this endowment $[0,100]$ he or she desires to bet in a lottery that returned three times the bet with one-half probability and nothing with one-half probability. As illustrated in the experimental instructions contained in Appendix C, subjects were made aware of the probabilities, the payoffs, and the fact that the lottery would be played

\footnotetext{
${ }^{14} \mathrm{We}$ thank an anonymous referee for urging us to proceed in this direction.

${ }^{15} \mathrm{We}$ also conducted a standard investment game (see, e.g., Fehr and List (2004)): we find no differences in propensities to invest across gender in either society. These results are available upon request. Additional tables are available as Supplemental Material (Gneezy, Leonard, and List (2009)).
} 
directly after choices were made. Subjects were therefore aware of the fact that they could earn anywhere between 0 and 300 units from this task. Last, subjects were informed that monies earned would be paid in private at the end of the experiment.

A few noteworthy items should be mentioned before proceeding to the results discussion. First, we chose the stakes to overlap with the stakes over which the ball tossing game would be played.$^{16}$ Second, experimental subjects for the risk aversion task are again drawn randomly from the two societal populations, but the subject pool has no overlap with the subject pool that played the ball tossing game. This was done to avoid contamination effects while still providing a glimpse of gender differences in risk preferences. Third, beyond using these data to dig deeper into the underlying mechanism at work in this environment, these data might be interesting in their own right considering the recent findings in Henrich and McElreath (2002). They reported that there are no systematic differences in the risk preferences of men and women in two traditional societies, including the Sangu, who live just south of the Maasai in Tanzania.

Table $\mathrm{V}$ presents the summary choices, split by gender across the two societies. In short, we report results consonant with Henrich and McElreath (2002): although the Khasi and Maasai appear to have different risk preferences, there are no gender differences observed in either society. ${ }^{17}$ Both male and female Khasi risk approximately 85 percent of their total endowment, whereas among the Maasai the average bet represents approximately 60 percent of the total endowment. A two-sample $t$-test rejects the hypothesis that the gambled amount for Khasi (Maasai) women is different from the gambled amount for Khasi (Maasai) men at the $p=0.74(p=0.92)$ level.

\subsection{Discussion}

Our data show that Khasi women are more likely to choose to compete than Khasi men. Furthermore, the Khasi women compete more often than Maasai women or any group of women in the various settings in which preferences for this type of behavior have been elicited. In the very least, these findings represent existence results: it is not universally true that the average female in every society avoids competition more often than the average male in that society because we have discovered at least one setting in which this is not true.

\footnotetext{
${ }^{16}$ In each group, the initial amount is equivalent to the payment for two successes if the participant chose piece rate, and the maximum payoff is equivalent to the payment for two successes if the participant chose competition and won.

${ }^{17}$ We should highlight that in a document titled "Internet Enhancements for 'Are Peasants Risk-Averse Decision-Makers', Henrich (2002a) expands on the results from Henrich and McElreath (2002) by showing that there are some differences between men and women in a pastoral Sangu village, but not between men and women in an agricultural Sangu village. Among the predominantly pastoral Maasai, we find no such difference.
} 
TABLE V

RAW DATA SUMMARY FOR THE RISK AVERSION GAME ${ }^{\mathrm{a}}$

\begin{tabular}{lcccc}
\hline \hline & \multicolumn{5}{c}{ Average Bet } \\
& \multicolumn{5}{c}{ (Standard Deviation) } \\
\cline { 2 - 5 } & Khasi & Khasi & Maasai & Maasai \\
& Women & Men & Women & Men \\
\hline Proportion bet & $86.5(3.3)$ & $85.0(4.0)$ & $60.7(4.1)$ & $61.3(4.2)$ \\
\hline
\end{tabular}

\footnotetext{
${ }^{\mathrm{a}}$ The amount in the cell is the average (standard deviation) amount bet of 100. A two-sample $t$-test (assuming equal variances) rejects the hypothesis that the bets for Khasi women are different from the bets for Khasi men $(p$ value 0.74$)$ and rejects the hypothesis that the bets for Maasai women are different from the bets for Maasai men ( $p$-value 0.92$)$.
}

To the best of our knowledge, this is the first demonstration of such reversal. In this section, we explore three possible explanations for this result: nature, nurture, and the co-evolution of nature and nurture.

In an extreme sense, one can consider the nature hypothesis to be one whereby women are inherently less competitive than men due to innate differences..$^{18}$ Our data rule out this simplistic view of gender and competition. However, the fact that Khasi women have different preferences than other women does not prove that their behavior is not genetically determined. It is possible that some feature of their environment caused the Khasi to follow a different evolutionary path and, therefore, to have different psychological profiles from other women. Were this true, matriliny and matrilocal marriage may be outcomes, not causes of female competitiveness. However, the evolution of behavioral characteristics is thought to take place on a scale that would rule out such a process. Evolutionary psychologists maintain that the human mind was formed by 1 million years of common evolution that ended only 12,000 years ago, and it is therefore impossible that systematic psychological differences across populations of humans can be caused by evolution (Daly and Wilson (1983), Campbell (2002)).

At the opposite end of the scientific spectrum, there is the view of human behavior as a "tabula rasa" (the mind as a blank slate). Thus, the nurture hy-

\footnotetext{
${ }^{18}$ This, of course, does not suggest that all women are less competitive than men, but rather there exists a difference in the distribution of types. A large body of literature in evolutionary biology and sociobiology documents differences in competitiveness between males and females across a myriad of species. Such differences in competitiveness are said to arise because of differences in the cost of reproduction and the level of investment in offspring. Because the costs associated with raising offspring are higher for females than for males, females will increase the fitness of their genes by insuring the survival of fewer children. Males, on the other hand, increase their fitness by competing for access to the most fertile or fit females. Thus, for women, reproductive success is partially independent of the success of other females, whereas for men, reproductive success comes at the cost of the success of other males. We direct the interested reader to Knight (2002) or Tregenza and Wedell (2002) for recent overviews. The debate is a classic in the field (see Darwin (1871), Bateman (1948), and Trivers (1972)).
} 
pothesis is that competitiveness differences are not due to biological or evolutionary reasons, but rather to culture. ${ }^{19}$ Gender socialization begins at the moment we are born, with the simple question "Is it a boy or a girl?" (Gleitman, Friedlund, and Reisberg (2000, p. 499)), and societal gender roles are taught to us by, or learned through the imitation of, family, peers, and the media. ${ }^{20}$ This view of human behavior has suffered a setback over the past few decades as evidence of the genetic origins of abnormal and normal behavior accumulates (Ilies, Avery, and Bouchard (2006)). For example, many personality traits have been shown to be highly hereditary in twin studies (Turkheimer (2004), Loehlin (1993)).

Notwithstanding this evidence that many behavioral traits are genetically determined, it is possible that preferences for competition are not and, therefore, that features of the culture or environment determine the degree to which females avoid or seek competition. Recent literature reminds us that subtle differences in culture can lead to large differences in behavior. Genetic endowments can strongly determine behavior within an environment, but may do a poor job of explaining differences across environments. For example, IQ (which many believe to be genetically determined) has increased at a rate of 0.30 points per year for at least the last 100 years (Flynn (2007, p. 112)). One reasonable interpretation of this fact is that genetic endowment leads to valid IQ differences within one cohort but not across cohorts facing widely differing environments. Madsen (1967) and Shapira and Madsen (1969) found differences in attitudes about cooperation versus competition between rural and urban children from similar cultures in Mexico, and urban and kibbutz children in Israel. Eisenberg and Mussen (1989) suggested that "in poor agricultural communities, children must cooperate in working with other members of their families to raise enough food for the family's survival." There is an extensive literature on the methods by which children learn behavior (Whitings (1963), Eisenberg and Mussen (1989), Harris (1998)). Thus, any number of subtle influences on children or adults can cause differences in attitudes to competition even if the behavior is broadly framed by genetic endowment.

\footnotetext{
${ }^{19}$ An entertaining twist highlighting the power of this argument can be found in the 1988 movie Twins, which starred Arnold Schwarzenegger, a physically perfect and innocent man, and his twin, Danny DeVito, a short, overweight small-time crook. Such differences are suggested to have occurred because Schwarzenegger was raised in a pristine environment, whereas DeVito spent his childhood on the streets.

${ }^{20}$ Socialization and gender socialization begins at early childhood (Martin, Wood, and Little (1990)), is taught by family, and is reinforced by culture (Burn (1996), Basow (1980), Crespi (2003)), teachers (Eisenberg and Mussen (1989)), and peers (Harris (1998)). Nothing in this process requires a view of culture as something forced on children. Indeed, the human species is particularly adept at social learning and many see enculturation as a process of voluntary imitation of successful individuals (Henrich and Gil-White (2001)). The socialization base of gender differences is not limited to young ages, see, for example, Riley, Bowless, Babcock, and Lai (2004).
} 
The underlying cultural differences between the Khasi and the Maasai offer room for speculation on environmental factors. Khasi girls are raised in the same household where they spend their whole lives (matrilocal) and, as heads of households, they enjoy significant authority over important decisions (matriliny). Thus, the fact that women can be raised exclusively for the benefit of their mothers' and grandmothers' households may mean that innate competitiveness does not need to be discouraged or competitiveness is encouraged. In addition, if pastoral groups such as the Maasai have different attitudes toward competition than agricultural groups such as the Khasi, this could help to explain the differences between Maasai men and Khasi men. ${ }^{21}$

Boyd and Richerson (2005) argued that social learning is a more natural form of cultural transmission than explicit training or socialization. Individuals may choose to copy successful individuals as much if not more than common individuals, and certainly do not need to be told that they should imitate. Whereas Maasai men are explicitly indoctrinated during the transition to manhood, Khasi women are not indoctrinated, but may choose to imitate the behavior of older women in their households or successful women in their social circles: prestige-based learning. Henrich and Gil-White (2001) suggested that freely conferred deference (prestige) is an adaptation that allows potential imitators proximity to individuals who represent models of successful behavior. This model of social learning highlights the facts that individuals may choose who to imitate, that access and proximity improve the fidelity of social learning, and that those who are imitated gains status from being imitated.

In this vein, the Khasi institutions of matrilocal residence and matrilineal inheritance may perform a similar role in cultural transmission. The fact that women live in (or next to) their maternal grandmothers' residences for their whole lives allows access and proximity (though only to mothers, aunts, great-aunts, and grandmothers). In addition, Khasi women are in a position to pass on accumulated wealth, and if competitiveness is differentially rewarded, women who learn competitiveness from their mothers will benefit both from their own efforts and from those of their mothers. Furthermore, female heads of households, even if they do not gain status by being imitated by their daughters, have an incentive to encourage success in their daughters. Unlike families in other societies, the household can gain directly from the long-term successes of their daughters.

We asked men and women in both cultures to perform unfamiliar tasks in an isolated setting where learning and imitation were not possible, however. Faced with a new task, Khasi men and women make a choice for themselves, based on their own preferences. Would women who are imitating competitive women choose to be competitive in an experimental setting? Does imitation lead to preferences for competition or simply preferences for activities that

\footnotetext{
${ }^{21}$ Henrich and McElreath (2002) suggested that risk preferences could vary between agricultural and pastoral groups, opening the possibility that competitive preferences may also differ.
} 
happen to be competitive? Henrich and McElreath (2002) suggested that men and women in Sangu and Mapucha cultures are risk-loving as revealed by their preferences in an experimental setting, but that imitation of successful men and women causes them to make choices in their everyday lives that reflect risk aversion. Imitated behavior is generally context-specific, whereas the experiment, if properly done, lacks cultural cues. If this view of the experimental setting is correct, Khasi women are not imitating the successful strategies of women when they choose competition; they are displaying their true preferences for competition.

Our data - and the fact that the experimental task reveals true, not imitated behavior-are also consistent with a series of models that are intermediate between those of nature and nurture. In such models, both biology and society play a role in forming preferences, not just observed behaviors, and allow for the impact of current societal features to be less important than the impact of past societal features. Those Khasi institutions that favor the transmission of a behavior through social learning also favor the transmission of genetically inherited characteristics, such as innate competitiveness. Many scholars suggest that the view of the human mind as undifferentiated across cultures fails to take into account the possibility that culture and genetics can interact. The study of gene-culture co-evolution in mathematical modeling suggests that when a particular genetic characteristic favors the transmission of a particular cultural feature, and that cultural feature also increases the fecundity of the genetic characteristic, evolution can occur at a much faster pace (Feldman and Cavalli-Sforza (1976), Cavalli-Sforza and Feldman (1981), Boyd and Richerson (1985, 2005), Laland and Brown (2002), Mesoudi and Laland (2007)).

The possibility of gene-culture co-evolution leads us to focus primarily on the institutions of matrilocal residence and matrilineal inheritance. First, as we have noted above, matrilocal residence creates a particular relationship between mothers, grandmothers, and daughters that benefits all three women. Second, matrilineal inheritance can reinforce any genetic tendency to competition by passing on both wealth and genetic disposition to daughters. In an environment of high childhood mortality, wealth can greatly increase the probability of survival. ${ }^{22}$ In addition, there is evidence that genetic inheritance is different in cultures that practice matrilocal marriage. Oota, SettheethamIshida, Twawech, Ishida, and Stoneking (2001) found significant variation in Y-chromosome features, but less variation in maternal DNA for matrilocal tribes in Thailand, and found the opposite for patrilocal groups in the same location. In other words, the cultural choice to displace men or women from their maternal homes, by itself, alters the process of genetic inheritance.

However, the very process that would favor genes linked to competitiveness (if they exist) would also favor competitiveness learned from the imitation of

\footnotetext{
${ }^{22}$ Indian census data from 1891-1911 suggests that only 50 percent of girls survived to the age of 15 (Mari Bhat (1989)). In addition, Pritchett and Summers (1996) estimated the short-term elasticity of child mortality with respect to income at about -0.2 .
} 
successful women. A model in which competitiveness improves the "evolutionary fitness" of the institutions of matriliny and matrilocal marriage, and the institutions of matriliny and matrilocal marriage increase the "evolutionary fitness" of competitiveness does not require biological evolution of DNA. Girls who imitate the behavior of successful competitive women are more likely to survive childhood and will inherit greater wealth if those women are also their mothers or grandmothers. In turn, their wealth and success make them more preferable as a model for younger girls (likely their daughters and nieces) and more likely to have surviving children.

This process is subtly different from that outlined under the nurture hypothesis. If competitiveness has evolved (biologically or socially) over time, it is not necessary that Khasi families teach their daughters to be competitive. Rather, the prevalence of competitiveness in the society could increase over time due to the superior fitness of this personality trait within this institutional environment, whether it is learned through imitation or is inherited genetically. In addition, this view suggests that current cultural features might be less important than past cultural features in explaining current preferences; evolution of socially learned behavior is not instantaneous.

\section{CONCLUDING REMARKS}

The link between gender and competition has been shown in several recent experimental studies. The importance of these results should not be understated: in both a positive and normative sense, these insights have the potential to explain important puzzles in economics and in social science more generally. In this study we use an experimental task to explore whether there are gender differences in selecting into competitive environments across two distinct societies: the Maasai in Tanzania and the Khasi in India. The societies are unique in that the Maasai represent an example of a patriarchal society, whereas the Khasi are matrilineal.

We observe some interesting data patterns. For example, Maasai men compete at roughly twice the rate as Maasai women, evidence that is consistent with data from Western societies that use different tasks and smaller relative stake levels. Yet, this data pattern is reversed among the Khasi, where women choose the competitive environment more often than Khasi men. We interpret these results as potentially providing insights into the underlying sources of the observed gender differences. We should, however, caution the reader that even though we find suggestive results, care should be taken when making inference from the data patterns observed herein because several important factors vary across the two societies. And, we have sampled a limited number of villages. We suspect that our results will not be a universal truth amongst all matrilineal villages, rather other important factors will interact with matriliny to produce the data patterns observed herein. More research is certainly warranted.

Viewed through the lens of extant models, our results might have import within the policy community. For example, policy-makers often are searching 
for efficient means to reduce the gender gap. If the difference in reaction to competition is based primarily on nature, then some might advocate, for example, reducing the competitiveness of the education system and labor markets to provide women with more chances to succeed. If the difference is based on nurture, or an interaction between nature and nurture, on the other hand, the public policy might be to target socialization and education at early ages as well as later in life to eliminate this asymmetric treatment of men and women with respect to competitiveness. Our study suggests that there might be some value in this second avenue. We trust that future research will refine this insight and more thoroughly explore the sources of gender preference differences.

\section{APPENDIX A: EXPERIMENTAL PROTOCOL (KHASI SESSIONS)}

Welcome to this study of decision-making. The experiment will take about 15 minutes. The instructions are simple, and if you follow them carefully, you can earn a considerable amount of money. All the money you earn is yours to keep and will be paid to you, in cash, immediately after the experiment ends. In addition to any earnings you might have in this task, you will be paid 20 rupees to participate.

The task that we ask you to perform today is throwing this ball into this bucket from this line. (Show them the ball, bucket, and line.) You will have 10 tries.

We now ask you to choose one of two options according to which you will be paid in the experiment.

OPTION 1: If you choose this option, you will get 20 rupees for each time you get the ball in the bucket in your 10 tries. So if you succeed 1 time, then you will get 20 rupees. If you succeed 2 times, then you will get 40 rupees. If you succeed 3 times, you will get 60 rupees, and so on.

OPTION 2: If you choose this option, you will receive a reward only if you succeed more times than the person who is playing in the next room. If you succeed more than this person, you will be paid 60 rupees for every time you succeed. So if you succeed 1 time, then you will get 60 rupees. If you succeed 2 times, then you will get 120 rupees. If you succeed 3 times, you will get 180 rupees and so on. But you will only receive a reward if you are better than the person in the next room. If you both succeed the same number of times, you will both get 20 rupees for each success.

We now ask you to choose how you want to be paid: according to Option 1 or Option 2. Now you may play.

Record both their ID number and their choice.

Allow the participant to toss the balls and record the result on the back of his/her ID card. You can record the result of each toss with a check mark and 
$X$ (check mark for success and $X$ for failure). At the end of the 10 tosses, write the total number of successes on the back of the card and the money value of each toss (based on his/her choice). Also write down whether his/her succeeded more than his/her opponent with Y or N.

For example, $\sqrt{ } \sqrt{ } \sqrt{ } \mathrm{V} / \mathrm{XX} \sqrt{ } \sqrt{ } 7 \mathrm{x} 20 \mathrm{Y}$.

You do not need to write the total payment on the card. Tell the participant he/she must go to the person who will fill out an exit survey. Once he/she has filled out this survey, he/she should take the card and the survey to the "cashier" and he/she will receive payment.

If they ask you what to do:

Tell them that you cannot give them advice about what to choose and offer to read the script to them again.

APPENDIX B: INDIVIDUAL CHARACTERISTICS SURVEY

(USED WITH KHASI AND MAASAI)

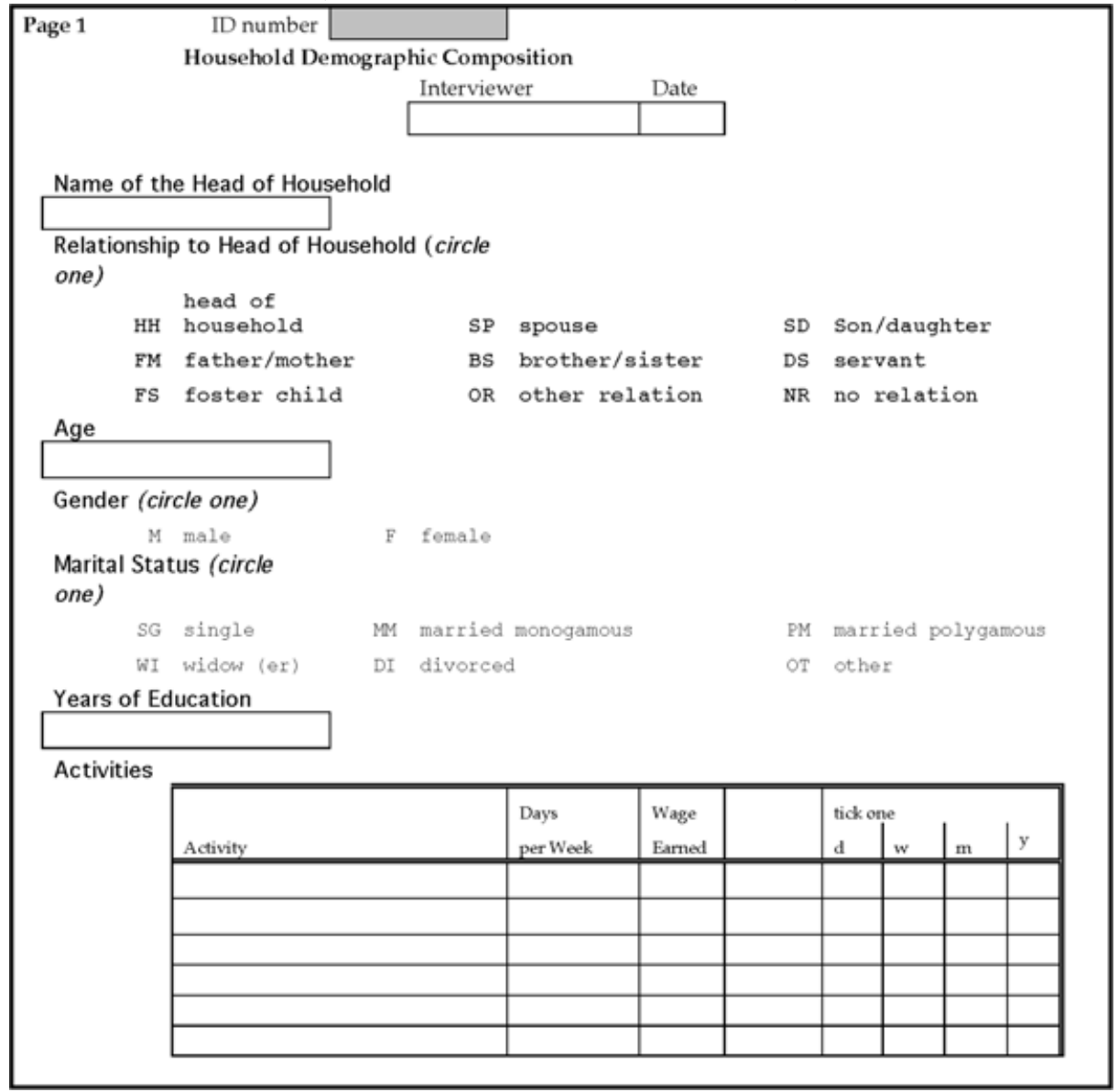




\section{APPENDIX C: EXPERIMENTAL INSTRUCTIONS FOR RISK AVERSION GAME (KHASI SESSIONS)}

Welcome to this study of decision-making. The experiment will take about 15 minutes. The instructions are simple, and if you follow them carefully, you can earn a considerable amount of money. All the money you earn is yours to keep and will be paid to you, in cash, immediately after the experiment ends. In addition to any earnings you might have in this task, you will be paid 20 rupees to participate.

At the beginning of this experiment you will receive 40 rupees. You are asked to choose the portion of this amount (between 0 and 40) that you wish to invest in a risky option. The rest of the money will be accumulated in your total balance.

The risky investment: there is an equal chance that the investment will fail or succeed. If the investment fails, you lose the amount you invested. If the investment succeeds, you receive 3 times the amount invested.

How do we determine if you win? After you have chosen how much you wish to invest, you will toss a coin to determine whether you win or lose. If the coin comes up heads, you win 3 times the amount you chose to invest. If the coin comes up tails, you lose the amount invested.

Examples

1. If you choose to invest nothing, you will get the 40 rupees for sure. That is, the coin flip would not affect your profits.

2. If you choose to invest all of the 40 rupees, then if the coin comes up heads, you win 120 rupees, and if the coin comes up tails, you win nothing and end up with 0 .

3. If you choose to invest 20 , then if the coin comes up heads, you win 80 $(20+3 * 20)$, and if the coin lands on tails, you win 20 .

Do you have any questions?

Ask them how much they would like to invest.

\section{REFERENCES}

AhMEd, S. Z. (1994): “What Do Men Want?” The New York Times, February 15th, A21. [1639, 1640]

ALTONJI, J. G., AND R. BLANK (1999): "Race and Gender in the Labor Market," in Handbook of Labor Economics, Vol. 3c, ed. by O. Ashenfelter and D. Card. Amsterdam: Elsevier, 3144-3259. [1637]

Agro-Economic Research Center for North EAST India, (1969): Rural Life in the Assam Hills: Case Studies of Four Villages. Studies in Rural Changes-Assam Series. Calcuta: K. L. Mukhopadhyaya. [1641]

BARon-CoHEn, S. (2003): The Essential Difference. Men, Women, and the Extreme Male Brain. London: Allan Lane. [1638]

BARRES BeN, A. (2006): "Does Gender Matter?" Nature, 442, 133-136. [1638]

BASOW, S. A. (1980): Sex-Role Stereotypes: Traditions and Alternatives. Monterey, CA: Brooks/Cole Publishing Company. [1655]

BATEMAN, A. J. (1948): “Intra-Sexual Selection in Drosophila,” Heredity, 2, 349-368. [1654] 
BLAU, F. D., AND L. M. KAHN (1992): “The Gender Earnings Gap: Learning From International Comparisons," American Economic Review, 82, 533-538. [1637]

(2000): “Gender Differences in Pay," Journal of Economic Perspectives, 14, 75-99. [1637]

Blau, F. D., M. Ferber, AND A. WinkLer (2002): The Economics of Women, Men and Work (Fourth Ed.). Englewood Cliffs, NJ: Prentice Hall. [1637]

BOYD, R., AND P. J. RiCHERSON (1985): Culture and the Evolutionary Process. Chicago: Chicago University Press. [1638,1657] [1638,1656,1657]

BURN, S. M. (1996): The Social Psychology of Gender. New York: McGraw-Hill. [1655]

CAMPBELl, A. A. (2002): Mind of Her Own: The Evolutionary Psychology of Women. Oxford, U.K.: Oxford University Press. [1637,1639,1654]

CAvalli-Sforza, L. L., AND M. W. FeldMAn (1981): Cultural Transmission and Evolution: A Quantitative Approach. Princeton, NJ: Princeton University Press. [1657]

CRESPI, I. (2003): "Gender Socialization Within the Family: A Study on Adolescents and Their Parents in Great Britain," available at http://www.iser.essex.ac.uk/files/conferences/bhps/2003/ docs/pdf/papers/crespi.pdf. [1655]

Cross, S. E., AND L. MEDSON (1977): “Models of Self: Self-Construals and Gender," Psychological Bulletin, 122, 5-37. [1649]

DALY, M., AND M. WILSON (1983): Sex, Evolution and Behavior. Belmont, CA: Wadsworth. [1654]

DARWIN, C. (1871): The Descent of Man, and Selection in Relation to Sex. London: John Murray. [1654]

Datta Gupta, N., A. Poulsen, And M. C. Villeval (2005): "Male and Female Competitive Behavior-Experimental Evidence," available at http:/ideas.repec.org/p/iza/izadps/dp1833. html. [1637,1651]

EISENBERG, N., AND H. PAul (1989): The Roots of Prosocial Behavior in Children. Cambridge: Cambridge University Press. [1655]

FEHR, E., AND J. A. LIST (2004): "The Hidden Costs and Returns of Incentives-Trust and Trustworthiness Among CEOS," Journal of the European Economic Association, 2, 743-771. [1652]

FELDMAN, M. W., AND L. L. CAVAlli-SforZa (1976): "Cultural and Biological Evolutionary Process, Selection for a Trait Under Complex Transmission,” Theoretical Population Biology, 9, 238-259. [1657]

FLYNN, J. R. (2007): What Is Intelligence?: Beyond the Flynn Effect. Cambridge: Cambridge University Press. [1655]

Gleitman, H., A. J. Fridlund, AND D. Reisberg (2000): Basic Psychology. New York: Norton \& Company. [1655]

GNEEZY, U., AND J. POTTERS (1997): "An Experiment on Risk Taking and Evaluation Periods," Quarterly Journal of Economics, 112, 631-645. [1652]

GNEeZy, U., AND A. Rustichini (2004): "Gender and Competition at a Young Age," American Economic Review Papers and Proceedings, May, 377-381. [1637]

(2005): "Executives versus Teachers: Gender, Competition and Selection," Working Paper, University of California, San Diego. [1637]

GNEEZy, U., K. L. LEONARD, AND J. A. LIST (2009): "Supplement to 'Gender Differences in Competition: Evidence From a Matrilineal and a Patriarchal Society'," Econometrica Supplemental Material, 77, http://www.econometricsociety.org/ecta/Supmat/6690_Tables.zip. [1652]

GNeEZy, U., M. NiederLe, AND A. Rustichini (2003): "Performance in Competitive Environments: Gender Differences," Quarterly Journal of Economics, 118, 1049-1074. [1637,1648,1651]

GoldBerg, S. (1993): Why Men Rule, a Theory of Male Dominance. Peru, IL: Open Court. [1639]

HAigh, M., AND J. A. LIST (2005): "Do Professional Traders Exhibit Myopic Loss Aversion? An Experimental Analysis," Journal of Finance, 60, 523-535. [1652]

HARRIS, J. R. (1998): The Nurture Assumption: Why Children Turn Out the Way They Do. New York: Free Press. [1655] 
HARRISON, G., AND J. A. LIST (2004): “Field Experiments,” Journal of Economic Literature, XLII, 1013-1059. [1642]

HENRICH, J., AND F. J. GIL-White (2001): “The Evolution of Prestige: Freely Conference Deference as a Mechanism for Enhancing the Benefits of Cultural Transmission," Evolution and Human Behavior, 22, 165-196. [1655,1656]

HenRICH, J., AND R. MCELREATH (2002): “Are Peasants Risk-Averse Decision Makers,” Current Anthropology, 42, 172-181. [1653,1656,1657]

(2002a): "Internet Enhancements for 'Are Peasants Risk-Averse Decision-Makers'," available at www.psych.ubc.ca/ henrich/Website/Papers/riskenhancements.pdf. [1653]

Hodgson, D. L. (2000): "Gender, Culture and the Myth of the Patriarchal Pastoralist," in Rethinking Pastoralism in Africa, ed. by D. L. Hodgson. London: James Currey. [1639,1641]

(2001): Once Intrepid Warriors: Gender, Ethnicity, and the Cultural Politics of Maasai Development. Bloomington, IN: Indiana University Press. [1639,1641]

ILIES, R., R. D. ARVEy, AND T. J. Bouchard (2006): "Darwinism, Behavioral Genetics, and Organizational Behavior: A Review and Agenda for Future Research," Journal of Organization Behavior, 27, 121-141. [1655]

KNIGHT, J. (2002): "Sexual Stereotypes," Nature, 415, 254-256. [1654]

LALAND, K. N., AND G. BROWN (2002): Sense and Nonsense: Evolutionary Perspectives on Human Behavior. Oxford, U.K.: Oxford University Press. [1657]

LaWrence, P. A. (2006): "Men, Women, and the Ghosts in Science," PLOS Biology, 4, 13-15. [1638]

LESOROGOL, C. K. (2003): "Transforming Institutions Among Pastoralists: Inequality and Land Privatization," American Anthropologist, 105, 531-541. [1641]

LoEHLin, J. (1993): "Nature, Nurture and Conservatism in the Australian Twin Study," Behavior Genetics, 23, 287-290. [1655]

MAdSEN, M. C. (1967): "Cooperative and Competitive Motivation of Children in Three Mexican Subcultures," Psychological Reports, 20, 1307-1320. [1655]

MARI BHAT, P. N. (1989): "Mortality and Fertility in India, 1881-1961: A Reassessment," in India's Historical Demography: Studies in Famine, Disease and Society, ed. by T. Dyson. London: Curzon, 73-118. [1657]

MARTin, C. L., J. K. LitTLE, AND C. H. Wood (1990): "The Development of Gender Stereotype Components," Child Development, 61, 1891-1904. [1655]

Mesoudi, A., AND K. N. LALAND (2007): "Culturally Transmitted Paternity Beliefs and the Evolution of Human Mating Behaviour," Proceedings of the Royal Society of London, Ser. B, 274, 1273-1278. [1657]

NAKANE, C. (1967): Garo and Khasi: A Comparative Study in Matrilineal Systems. Paris: Mouton \& Co. [1640]

Niederle, M., AND L. Vesterlund (2005): "Do Women Shy Away From Competition? Do Men Compete too Much?" available at http://www.stanford.edu/ niederle/Women. Competition.pdf. [1637]

(2007): "Do Women Shy Away From Competition? Do Men Compete too Much?" Quarterly Journal of Economics, 122, 1067-1101. [1651]

NONGBRI, T. (1988): "Gender and the Khasi Family Structure: The Meghalaya Succession to Self-Acquired Property Act, 1984,” Sociological Bulletin, 7, 71-82. [1640]

[1641]

(2003): Development, Ethnicity and Gender. Jaipur/New Delhi: Rawat Publications.

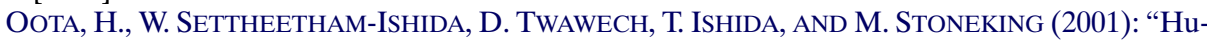
man $m \mathrm{tDNA}$ and Y-chromosome Variation Is Correlated With Matrilocal versus Patrilocal Residence," Nature Genetics, 29, 20-21. [1657]

PritchetT, L., AND L. H. Summers (1996): "Wealthier Is Healthier," The Journal of Human Resources, 31, 841-866. [1657]

RidLEY, M. (2003): Nature via Nurture. New York: Harper Collins. [1638] 
RILEy Bowless, H., L. BABCOCK, AND L. LAI (2004): "It Depends Who Is Asking and Who You Ask: Social Incentives for Sex Differences in the Propensity to Initiate Negotiation," available at http://www.ksg.harvard.edu/wappp/research/Bowles_Babcock_Lai.pdf. [1655]

SHAPIRA, A., AND M. C. MADSEN (1969): "Cooperative and Competitive Behavior of Kibbutz and Urban Children in Israel," Child Development, 40, 609-617. [1655]

SHELl, R. (2006): Bargaining for Advantage: Negotiation Strategies for Reasonable People (Second Ed.). New York: Penguin Books. [1638]

SpenCer, P. (1965): The Samburu; A Study of Gerontocracy in a Nomadic Tribe. Berkeley, CA: University of California Press. [1639,1640]

(1994): "Becoming Maasai, Being in Time," in Being Maasai: Ethnicity and Identity in East Africa, ed. by T. Spear and R. Waller. London: James Currey. [1639]

(2003): Time, Space and the Unknown: Maasai Configurations of Power and Providence. London: James Currey. [1640]

TregenZA, T., AND N. Wedell (2002): "Polyandrous Females Avoid Costs of Inbreeding,” Nature, 415, 71-73. [1654]

TRIVERS, R. L. (1972): "Parental Investment and Sexual Selection," in Sexual Selection and the Descent of Man, ed. by B. Campbell. Chicago: Aldine, 136-177. [1654]

Turkheimer, E. (1998): "Heritability and Biological Explanation," Psychological Review, 105, 782-791. [1638]

(2004): "Spinach and Ice Cream: Why Social Science Is so Difficult," in Behavior Genetics Principles: Perspectives in Development, Personality, and Psychopathology, ed. by L. F. DiLalla. Washington, DC: American Psychological Association. [1655]

Turkheimer, E., A. HALEY, M. WALDRON, B. D'ONOFRIO, AND I. I. GotTeSMAN (2003): “Socioeconomic Status Modifies Heritability of IQ in Young Children," Psychological Science, 14, 623-628. [1638]

VANDEgRIFT, D., A. YAVAS, AND P. Brown (2004): "Men, Women and Competition: An Experimental Test of Labor Market Behavior," Mimeo. [1637]

VAN HAM, P. (2000): The Seven Sisters of India: Tribal Worlds Between Tibet and Burma. Munich, London, and New York: Prestel Publishers. [1640]

Whitings, B. B. (1963): Six Cultures: Studies of Child Rearing. New York: Wiley. [1655]

Rady School of Management, University of California-San Diego, Otterson Hall, 9500 Gilman Dr., La Jolla, CA 92093-0553, U.S.A.; ugneezy@ucsd.edu,

University of Maryland, 2200 Symons Hall, Colledge Park, MD 20783, U.S.A.; kleonard@arec.umd.edu,

and

Dept. of Economics, University of Chicago, 1126 East 59th Street, Chicago, IL 60637, U.S.A., NBER, and Dept. of Economics, CentER, PO Box 90153, 5000 LE Tilburg, The Netherlands; jlist@uchicago.edu.

Manuscript received September, 2006; final revision received December, 2008. 